\title{
Um material é mais que um substantivo, é a antecipação de um encontro
}

\author{
GUSTAVO VICENTE
}

Fernando Matos Oliveira (ed.), Conceitos e dispositivos de criação em artes performativas, Imprensa da Universidade de Coimbra, 2017, 269 pp.

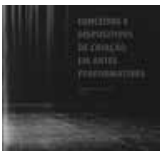

1. Este livro dá acesso ao «conjunto de materiais» - como é descrito na contracapa - apresentados no Colóquio Internacional com o mesmo nome, ocorrido em Coimbra, entre 26 e 28 de Novembro de 2015. A referência a materiais - em vez de textos, artigos ou comunicações, como é comum neste tipo de volumes - parece muito justa, uma vez que, além de expressar a sua variedade formal, dá conta da qualidade material que atravessa todo o livro. Com efeito, os materiais reunidos nesta publicação manifestam, na sua larga maioria, uma relação sensível com a prática do pensar e do fazer artísticos - seja a convocar o carácter imanente das interpretações conceptuais sobre a criação artística (capítulo I: Conceitos), a imergir na auto-reflexão sobre processos singulares de experimentação (capítulo II: Dispositivos) ou a dar a ver formas alternativas de mediação estética (capítulo III: Remediações).

O texto de Eduarda Neves que abre o primeiro capítulo, por exemplo, dá o mote para o que lhe sucederá, abordando a génese do termo dispositivo, não só do ponto de vista da sua origem foucaultiana, como da perspectiva do seu alcance performativo, patente logo no título: Um dispositivo é mais que um adjectivo, é mais que um substantivo. Esta predisposição para dar mais «corpo» às deambulações conceptuais mantém-se através das propostas de mapeamento cognitivo na dança (Ana Mira); de reflexão sobre a proximidade (Susana Mendes Silva) e co-criação (Francesca Rayner) entre performers e audiência; de aplicação da matemática ao estudo do movimento (Telma João Santos); de análise do impacto performativo da cenografia (Filipa Malva) ou de estabelecimento da rede de relações possível entre roupa, corpo e performance (Simone Mina). O segundo capítulo invoca a materialidade da experiência artística, abordando a forma como a activação de diversos dispositivos afecta a percepção dos espectadores. Aqui, embrenha-se no temperamento do jogo dramático (Ricardo Seiça Salgado); nos efeitos biopolíticos da 
identidade de género na criação artística (André Rosa); nas disrupções sensoriais inerentes ao uso de soluções digitais em palco (Vítor Joaquim); nas possibilidades de articulação multimédia na performance site-specific (Frederico Dinis) ou nos ecodispositivos postos em acção por Vera Mantero (Fernando Matos Oliveira). O terceiro capítulo é, porventura, a secção do livro onde essa qualidade material mais se adensa, uma vez que aborda formas concretas de mediação artística. A particularidade da relação entre o teatro e a fotografia estereoscópica (Cláudia Madeira); a hibridez da relação entre corpo e vídeo-performance (Regilene Sarzi-Ribeiro) e entre espectador-participante e instalação intermedia (Isabel Maria Dos); o carácter documental do teatro (Sara Jobard) ou a manifestação cénica de conceitos científicos (Mário Montenegro) são todos exemplos da procura da «matéria enquanto revelação», como diria Artaud. ${ }^{1} \mathrm{Ou}$ seja, dos aspectos reveladores da(s) prática(s) vivida(s) que as artes performativas intensificam e que nos permitem entrar em contacto com diferentes «modos de criar mundo e de abrir novos horizontes sensoriais e cognitivos», como refere Fernando Matos Oliveira na Introdução. O próprio cuidado posto na edição gráfica do livro convida a esta relação corpórea com o objecto, fazendo salientar a materialidade inerente ao encontro proporcionado pelas artes performativas. No fundo, aludindo ao que Ana Mira descreve no seu texto como «documento sensível», que pode ser extrapolado para o contexto deste livro na medida em que este incorpora a matéria expressiva de uma multiplicidade de corpos que dançam, representam, encenam, tocam, coreografam, cantam, escrevem, fotografam, assistem, ou simplesmente escutam, olham e reconhecem a massa transformadora da criação artística.

2. Numa edição deste género, existe, por vezes, a tentação de «arrumar» aquilo que não tem arrumação possível (nem desejável), ou de tentar homogeneizar a diversidade de olhares sob uma única lente; mas esse não é o caso deste livro. Apesar de o título e divisão por capítulos poder apontar para uma lógica de normalização sequencial entre o pensamento teórico (conceitos), as estruturas de regulação estética (dispositivos) e a prática artística (criação), a verdade é que isso não obscurece a forma como essas componentes se entrelaçam e confundem, nem apaga as valências inerentes ao cruzamento de tópicos e pontos de vista. Pelo contrário, o enquadramento dado por Fernando Matos Oliveira na Introdução, bem como a abertura temática do seu índice, promovem

1 Antonin Artaud (2016), A arte e a morte, Lisboa, Sr. Teste/Ignota. uma leitura cruzada que dá uma nova luz aos textos individuais. A multiplicidade aqui é encarada de forma substantiva, dando-se a ver as possibilidades de combinação entre textos e contextos de análise e a forma como estes se desdobram noutras conexões potenciais. Para isto, a qualidade das várias contribuições é fundamental, especialmente na medida em que expõem dialécticas onde as interrogações se mantêm vivas e em constante relação. «Porque aspira a arte a uma vontade de verdade?» (Eduarda Neves); «Quão próximos podemos estar na performance?» (Susana Mendes Silva); «Who do we call a performer, a participant and a spectator [...]?» (Francesca Rayner); «Qual a relação entre o corpo performático e a linguagem do vídeo?» (Regilene Sarzi-Ribeiro) são algumas das questões lançadas nos textos que, de alguma forma, dialogam entre si e se abrem para outras, com as quais se relacionam por proximidade temática, comparação disciplinar ou outro tipo de afinidade epistemológica. Neste sentido, o livro dá a ver, no seu todo, o alcance e a complexidade da rede de relações que o estudo das artes performativas envolve a diversos níveis de análise.

3. Todas estas questões são correspondentes da mesma inquietação primordial que André Rosa manifesta no seu texto quando, a certa altura da sua escrita, o autor «pára» para se interrogar: «O que é que isto nos revela?» Esta é a pergunta que todos fazemos enquanto artistas, investigadores ou simples espectadores quando confrontados com qualquer prática criativa em particular. Não é uma pergunta sobre a natureza universal das artes, mas sobre a singularidade dos fenómenos artísticos. É precisamente esta atenção dada ao carácter singular das práticas artísticas que imprime ao livro o seu cunho intemporal; uma vez que a maioria dos seus textos aborda processos de criação e/ou eventos artísticos específicos - sobre os quais não pode haver qualquer tipo de «actualização» histórica, mas apenas o lastro deixado pela memória dos acontecimentos. Nesta perspectiva, o livro constitui também um instrumento de «salvaguarda criadora», como definiu Heidegger ${ }^{2}$ a propósito da preservação das «obras de arte». Este acto de salvaguarda é fundamental para quem faz investigação artística, pois é a partir dos seus alicerces que é possível ir acumulando saberes sobre a diversidade das práticas artísticas - especialmente as que ocorrem na esfera das artes performativas, cujo carácter efémero e marcadamente vivencial exige um esforço contínuo de rememoração e contextualização.

2 Martin Heidegger (2019), A origem da obra de arte, Lisboa, Edições 70. 
4. A multiplicidade de vozes presentes em Conceitos e Dispositivos de Criação em Artes Performativas abre as portas para uma outra multiplicidade - nomeadamente a que é edificada pelos seus leitores potenciais. Do estudante iniciado ao investigador mais experiente, todos encontram, num ou noutro texto, numa ou noutra perspectiva, uma ressonância familiar ou provocadora. E todos encontram, no geral, a possibilidade de entrar em contacto com uma amostra relevante do panorama de investigação das artes performativas, sobretudo a que ocorre em Portugal. Neste contexto, teria sido vantajoso poder contar com pequenas biografias dos autores que contribuem para este volume, de modo que pudéssemos traçar um outro tipo de cartografia composta por quem pensa/ /faz, como tem pensado/feito e onde se encontra a pensar/fazer dentro da trama de artistas-investigadores que compõem este universo de estudos. Nada, no entanto, que o omnipresente dispositivo googliano não ajude a re-mediar. 